\title{
Extreme breeding effort of Common Kingfisher (Alcedo atthis)
}

\author{
Extrémne hniezdne úsilie rybárika riečneho (Alcedo atthis)
}

\section{Lucia Rubáčová \& Mária MelišKovÁ}

Department of Zoology, Faculty of Natural Sciences Comenius University, Bratislava, Ilkovičova 6, Mlynská Dolina, 84215 Bratislava 4, Slovak Republic; e-mail: lucia.turcokova@uniba.sk

\begin{abstract}
The Common Kingfisher (Alcedo atthis) has a fairly long breeding season in Central Europe. Birds start to breed at the end of March and finish early in September. In this time they can successfully breed two, three or four times per season. The study of kingfisher breeding biology in Danube river system (southwestern Slovakia) brought interesting discovery. In 2018, we documented the extremely long breeding period of an individual breeding pair of Kingfisher at the locality of Fodráska, where the first egg was laid on March 30, while the last young were expected to leave the nest on September 30, 2018. The pair attempted to breed five times, of which three attempts were successful with totally 19 raised chicks. The length of breeding season was estimated on around 185 days. This is one of the longest documented breeding seasons in this species and the latest date of breeding observed in the Central Europe.
\end{abstract}

Key words: kingfisher, breeding biology, brood number, length of breeding season

The Common Kingfisher belongs to the species with extremely long breeding period. It can begin at the end of March and finish in July (Hudec \& Št’astný 2005), August (Kucharski \& Čech 2009), or in the end of September (Čech 2010; Turčoková et al. 2016) in Central Europe. The mean length of the breeding season takes from 136 days (min.-max.: 120-145) in Poland to 164 days (min.-max.: 140-185) in the Czech Republic (values on the level of local populations, not related to individual pairs; Kucharski \& Čech 2009). Kingfishers regularly breed two times per season, occasionally three times and exceptionally up to four times (Morgan \& Glue 1977; Cramp 1985; Novotný 1994, Woodall 2001). There is no evidence of five broods produced by one breeding pair per season. Moreover, there is no evidence of kingfisher's breeding at the very end of September in Central Europe.
We monitored breeding population of the kingfishers from March to September 20142018 in the Danube river system from Bratislava $\left(48^{\circ} 06^{\prime} 13.5^{\prime \prime} \mathrm{N} 17^{\circ} 09^{\prime} 31.3^{\prime \prime E}\right)$ to Gabčíkovo $\left(47^{\circ} 52^{\prime} 32.1^{\prime \prime} \mathrm{N} 17^{\circ} 31^{\prime} 18.0^{\circ} \mathrm{E}\right)$. In late April we started to search for new nesting burrows and checked the known ones for the presence of active nests. Occupied burrows were inspected weekly using miniature camera (Probe Maxivideo MV 201). Parents were captured to mist net installed nearby the nest bank during the feeding of the young. Nestlings were very carefully extracted from the nesting chamber using a special tool. Subsequently, they were ringed at the age at least 14 days and gently pushed back into the burrow. We continued to control nest burrows after chicks ringing because of possibility of repeated breeding attempt in the same burrow. 
In 2018 we documented one of the longest breeding season of individual pair at the locality of Fodráska (4752’20.40”N , 17³1'13.01'E). A female laid the first egg on March 30. After the five breeding attempts the last chicks were expected to leave the nest on September 30. The first nesting was unsuccessful from an unknown reason. On April 30, all six young (approximately 5 days old) were found freshly dead in the nesting burrow. The adults fluttered and whistled around. At the same time, freshly excavated new nesting hole was found on the opposite bank. It seemed that parents started to excavate the new hole, while still cared about previous offspring in the nest. Seven eggs were found in new burrow during the next control. Although, the both parents were ringed during the second breeding attempt, it is likely that it was the same pair we observed during the first breeding attempt. This breeding was not successful, due to the collapse of the bank. After the two unsuccessful attempts, ringed parents (male: M12059, female: M12086) were observed to excavate a new hole and to breed third time (Table 1). Parents successfully breed three times and alternated two holes (the new hole and the old, firstly used hole). Female laid altogether 33 eggs during five attempts and together with a male successfully raised 19 chicks (all were ringed). Documented number of chicks is consistent with average seasonal breeding success of one breeding pair observed in other populations (Cramp 1985, Woodall
2001), while the maximum number of fledged chicks reared by one pair within the season (in three or four broods) may move between 26 to 28 (Turčoková et al. 2016; P. Čech pers. com.; own obs.). The young from the last breeding attempt were in excellent condition while ringed on September 24 as 19 days old. The date of leaving the nest was assumed on September 30 , based on young's age. The length of the breeding was estimated on around 185 days. For comparison, Danube pairs successfully breeding four times per season have the length of breeding season in average of 160 days (minimum $=$ 151 , maximum $=173$ days, $n=6$ ) and finish in mid-September (own unpublished data). In the Czech Republic, the season may finish in the middle of September (Čech 2010). In Poland, the season is shorter and ceases at the end of August (Kucharski \& Čech 2009).

As parents were not ringed and even observed during the first breeding attempt, one of the partners could die, and then survivor left the nest and let the young die. However, it is generally known in birds that the partner is capable to raise chicks in most cases alone (Winkler 1987). The second option is the strong nesting competition between breeding pairs causing displacement of the breeding pair. This may happen when the density is high and consequently, the distances between nests are less than $200 \mathrm{~m}$ (Čech 2017). This is not a case at locality of Fodráska, where the distance from the neighbouring burrow was $1.24 \mathrm{~km}$. In ad-

Table 1. Laying date, clutch size, brood size and nest fate of unusual five successive breeding attempts of a Common Kingfisher pair at Fodráska locality in 2018. In the second breeding attempt we were not able to closely estimate laying date, because the bank collapsed with eggs.

Tab. 1. Dátum znesenia prvého vajca, vel'kost' znášky, počet mlád'at a osud piatich hniezdnych pokusov jedného hniezdneho páru rybárika riečneho na lokalite Fodráska v roku 2018. Pri druhom hniezdnom pokuse nebolo možné bližšie určit dátum znesenia prvého vajca, pretože sa hniezdny breh zosunul v čase inkubácie znášky.

\begin{tabular}{ccccc}
\hline $\begin{array}{c}\text { Brood order / } \\
\text { Poradie znášky }\end{array}$ & $\begin{array}{c}\text { Laying date / } \\
\text { Dátum liahnutia }\end{array}$ & $\begin{array}{c}\text { Clutch size / } \\
\text { Vel'kost' znášky }\end{array}$ & $\begin{array}{c}\text { Brood size / } \\
\text { Počet mlád'at }\end{array}$ & Nest fate / Osud hniezdenia \\
\hline 1 & March 30 / 30.3. & 6 & 6 & young died / mlád'atá zahynuli \\
2 & $\begin{array}{c}\text { May 1 - May 17 / } \\
\text { 1.5. - 17.5. }\end{array}$ & 7 & 7 & bank collapsed / breh sa zrútil \\
3 & June 4 / 4.6. & 7 & 6 & young fledged / mlád'atá vyleteli \\
4 & July 3 / 3.7. & 7 & 7 & young fledged / mlád'atá vyleteli \\
5 & August 9 / 9.8. & 6 & 6 & young fledged / mlád'atá vyleteli \\
\hline
\end{tabular}


dition, after the partner's loss as well as after the displacement of the breeding pair, it took several days for the new pair to start breeding. The observed breeding attempts were overlapping, which increased the probability that all five broods belonged to the same breeding pair. Indeed, the case of one pair or one individual, respectively, breeding five times in the season is unusual.

Five documented broods were only possible due to failure of two brood attempts at the beginning of the season. Otherwise, five successful broods (of one pair) seem to be on the absolute seasonal limit of kingfisher. Even in case of significantly overlapping broods and absolutely precise timing of egg laying, the breeding season would end somewhere at the beginning of October. Rearing of multiple successful broods within one breeding season is only possible due to effective hunting and providing large and energetically rich prey (Čech \& Čech 2017), that occurs in the branches of Danube river (Kováč 2015). Such breeding effort is extremely demanding to parental birds and strongly affects their survival to the next year. Usually, these individuals are not present in the population next season (P. Čech, pers. com, own obs.).

\section{Acknowledgements}

Funding for this research in Slovakia was supplied by grant LIFE12 NAT/SK/001137. Permission to carry out the study was granted by Ministry of the Environment of the Slovak Republic. We thank to M. Baláž and M. Čech for truthful comments, which improved the manuscript.

\section{Súhrn}

Rybárik riečny má v strednej Európe pomerne dlhú hniezdnu sezónu, trvajúcu od konca marca do polovice septembra, počas ktorej dokáže vyhniezdit’ dva, tri či dokonca štyrikrát. Výskum hniezdnej biológie rybárikov v ramennej sústave Dunaja (juhozápadné Slovensko) priniesol zaujímavý objav. V roku 2018 sme zdokumentovali jedno z najdlhších období rozmnožovania rybárika riečneho u jedného hniezdneho páru na lokalite Fodráska, pri ktorom zniesla samica prvé vajce 30. marca. Po piatich pokusoch o zahniezdenie (z toho troch úspešných) posledné mlád'atá opustili hniezdo odhadom 30. septembra. Rodičia úspešne vyhniezdili trikrát, vystriedali dve nory a celkom odchovali 19 mlád'at. Dížka hniezdenia bola odhadnutá na 185 dní. Toto hniezdenie patrí medzi jedno z najdlhších zdokumentovaných hniezdení a taktiež medzi najneskoršie vyhniezdenia tohto druhu v strednej Európe.

\section{References}

Cramp S. 1985: The Birds of the Western Palearctic, Vol. IV. - Oxford University Press, Oxford \& New York.

ČECH P. 2010: Length of the breeding season of the Eurasian Kingfisher (Alcedo atthis) in the Czech Republic. Sylvia 46: 53-61.

ČECH P. 2017: Findings to the territoriality of the Common Kingfisher (Alcedo atthis) and their use in the fieldwork (when monitoring the nesting density and when studying the dynamics of its regional population). - Pp.: 44-55. In: ČECH P. (ed.): Sborník referátů z III. mezinárodního semináře Ledňáček říční (Alcedo atthis) jeho ochrana a výzkum. ZO ČSOP Vlašim.

ČECH M. \& ČECH P. 2017: Effect of brood size on food provisioning rate in Common Kingfishers Alcedo atthis. - Ardea 105(1): 5-17.

Hudec K. \& ŠŤAstný K. 2005: Fauna ČR. Ptáci II/2. Academia, Praha.

Kováč V. 2015: Current status of fish communities in the Danube. - Pp.: 359-388. In: LiskA I. (ed.): The Danube River Basin. Springer-Verlag Berlin Heidelberg.

Kucharski R. \& Čech P. 2009: Comparison of Kingfishers nesting course in Bohemia and in Northern Poland in years 2008-2008. - Pp.: 52-59. In: ČECH P. (ed.): Sborník referátů z II. mezinárodního semináře Ledňáček říční (Alcedo atthis), jeho ochrana a výzkum. ZO ČSOP Vlašim.

Morgan R. \& GLue D. 1977: Breeding, mortality and movements of Kingfishers. - Bird Study 24: 15-24.

Novotný K. 1994: Four breeding attempts of Eurasian Kingfisher (Alcedo atthis) in one season. - Sylvia 30: 148-151. 
Turčoková L., MelišKová M. \& Balážová M. 2016: Nest site location and breeding success of Common Kingfisher (Alcedo atthis) in the Danube river system. - Folia Oecologica 43: 74-82.

WinkLeR D. W. 1987: A general model for parental care. American Naturalist 130: 526-543.
Woodall P. F. 2001: Family Alcedinidae (Kingfishers). Pp.: 130-244. In: del Hoyo J., Elliott A. \& Sargatal J. (eds.): Handbook of the Birds of the World, Vol. 6, Mousebirds to Hornbills. Lynx Edicions Barcelona.

Received: 3. 2. 2020

Accepted: 21. 2. 2020

Online: 25. 2. 2020 